\title{
Profesionalisme guru sebagai determinan terhadap prestasi belajar siswa
}

\author{
(Teachers' profesionalism as determinant towards students' learning \\ achivement)
}

\author{
Intan Permatasari', A. Sobandi ${ }^{2 *}$ \\ 1,2Program Studi Pendidikan Manajemen Perkantoran, \\ Fakultas Pendidikan Ekonomi dan Bisnis, Universitas Pendidikan Indonesia \\ Jl. Dr. Setiabudhi, No. 229 Bandung, Jawa Barat Indonesia \\ Email: ade@upi.edu
}

\begin{abstract}
ABSTRAK
Rendahnya prestasi belajar siswa menjadi inti permasalahan dalam penelitian ini. Nilai akhir siswa yang belum mencapai Kriteria Ketuntasan Minimum (KKM) di Sekolah merupakan indikasi terhadap permasalahan yang diteliti. Artikel ini bertujuan untuk memaparkan hasil penelitian tentang pengaruh profesionalisme guru terhadap prestasi belajar siswa kelas X Administrasi Perkantoran di salah satu Sekolah Menengah Kejuruan (SMK) swasta di Lembang. Penelitian ini menggunakan metode eksplanatory survey, dengan teknik pengumpulan data menggunakan angket yang diberikan kepada responden sebanyak 81 orang siswa. Hasil analisis data menunjukan bahwa profesionalisme guru berada pada kategori cukup baik dan prestasi belajar siswa berada pada kategori sedang. Namun demikian, profesionalisme guru berpengaruh positif dan signifikan terhadap prestasi belajar siswa baik secara simultan maupun parsial. Maka, untuk meningkatkan prestasi belajar siswa perlu diadakannya peningkatan dan pengembangan dalam profesionalisme guru.
\end{abstract}

Kata kunci: Profesionalisme Guru; Prestasi Belajar Siswa

\begin{abstract}
The low level of student learning is the core problem in this study. The final score of students who have not reached the Minimum Completion Criteria in the School is an indication of the problems studied. This article aims to reveal the results of study on teachers' profesionalism effects towards X class students' learning achievement, Office Administration Expertise Program at one of vocasional school at Lembang. This study applied eksplanatory survey research method and questionnaire as technique for collecting the data. The questionnaires were distributed to 81 students. The results of data analysis indicate that teachers' profesionalism is at fairly good level and students's learning achievement is at medium level. In relation to this point, teachers' profesionalism affects positively and significantly towards students' learning achievement simultaneously and
\end{abstract}

Received: Februari 2019, Revision: Mei 2019, Published: Juli 2019 
partially. To gain students' learning achievement, teachers' profesionlism needs to be developed and improved.

Keywords: Teacher Professionalism; Students Achievement

\section{PENDAHULUAN}

Prestasi belajar merupakan harapan semua siswa termasuk guru dan sekolah. Hal ini juga bisa menunjukkan tercapainya tujuan pembelajaran. Prestasi belajar merupakan penguasaan pengetahuan atau keterampilan pada materi pembelajaran yang hasilnya berupa nilai-nilai dari tes atau ujian serta tugas-tugas yang diberikan oleh guru sebagai ukuran kecakapan dengan jumlah nilai akhir. Upaya peningkatan prestasi belajar harus lebih banyak dilakukan oleh para guru, sebab guru yang berinteraksi langsung dalam membina para siswa di sekolah melalui proses belajar mengajar. El Anzi (dalam Latipah, 2010, hlm. 113) menyatakan bahwa prestasi belajar merupakan salah satu tolak ukur dari keberhasilan seseorang dalam akademik.

Prestasi belajar yang baik pada hakekatnya akan merupakan harapan setiap siswa dan juga guru pada setiap proses pembelajaran. Namun, pada kenyataannya prestasi belajar yang diperoleh siswa tidak selalu baik dan sesuai dengan standar KKM yang telah ditetapkan sebagai patokan keberhasilan proses pembelajaran. Begitu pula yang terjadi di salah satu SMK swasta di Lembang khususnya pada mata pelajaran kearsipan yang tertera pada tabel berikut:

Tabel 1

Rekapitulasi Nilai Akhir Mata Pelajaran Kearsipan Kelas X Administrasi Perkantoran Tahun Ajaran 2013/2014-2015/2016

\begin{tabular}{|c|c|c|c|c|c|}
\hline \multirow{2}{*}{$\begin{array}{l}\text { Tahun } \\
\text { Ajaran }\end{array}$} & \multirow[t]{2}{*}{ Kelas } & \multirow[t]{2}{*}{ KKM } & \multirow{2}{*}{$\begin{array}{l}\text { Jumlah } \\
\text { Siswa }\end{array}$} & \multicolumn{2}{|c|}{ Pengetahuan (KI-3) } \\
\hline & & & & $<$ KKM & $\begin{array}{c}\text { Presentase } \\
(\%)\end{array}$ \\
\hline \multirow[t]{2}{*}{ 2013-2014 } & X AP 1 & \multirow[t]{6}{*}{75} & 42 & 5 & 11,90 \\
\hline & X AP 2 & & 33 & 5 & 15,15 \\
\hline \multirow[t]{2}{*}{ 2014-2015 } & X AP 1 & & 38 & 12 & 31,57 \\
\hline & X AP 2 & & 39 & 14 & 35,89 \\
\hline \multirow[t]{2}{*}{$2015-2016$} & X AP 1 & & 34 & 14 & 41,17 \\
\hline & X AP 2 & & 45 & 19 & 42,22 \\
\hline
\end{tabular}

Sumber: Dokumen Legger di salah satu SMK swasta di Lembang (data diolah)

Tabel 1 menggambarkan prestasi belajar siswa pada mata pelajaran kearsipan pada tahun ajaran 2013-2014. Siswa yang belum mencapai KKM untuk kelas X AP 1 dengan jumlah sebanyak 42 siswa yaitu, 5 siswa dengan presentase sebesar 11,90\%. Untuk kelas X AP 2 siswa yang belum mencapai KKM dengan jumlah sebanyak 33 siswa yaitu, 5 siswa dengan presentase sebesar 15,15\%. Pada tahun ajaran 2014-2015, siswa yang belum mencapai KKM untuk kelas X AP 1 dengan jumlah siswa sebanyak 38 siswa yaitu, 12 siswa dengan presentase sebesar 31,57\%. Untuk kelas X AP 2, siswa yang belum mencapai KKM dengan jumlah sebanyak 39 siswa yaitu, 14 siswa dengan presentase sebesar 35,89\%. Pada tahun ajaran 2015-2016, siswa yang belum mencapai KKM untuk kelas X AP 1 dengan jumlah 34 siswa yaitu, 14 siswa dengan presentase sebesar 41,17\%. Untuk kelas X AP 2, siswa yang belum mencapai KKM dengan jumlah 45 siswa yaitu, 19 siswa dengan presentase sebesar 42,22\%. Hal tersebut memperlihatkan bahwa prestasi belajar siswa dilihat dari rata-rata nilai akhir aspek 
kognitif mengalami naik turun (fluktuasi) pada setiap semesternya yang menunjukkan prestasi belajar siswa perlu diperbaiki.

Bloom (dalam Sudjana, 2013, hlm. 39) menyatakan bahwa ada dua faktor yang dapat mempengaruhi prestasi belajar yaitu faktor internal seperti minat, bakat, cara belajar, dan sebagainya, serta faktor eksternal seperti guru, keluarga, masyarkat, lingkungan, dan sebagainya. Profesioanlisme guru merupakan salah satu faktor eksternal yang memengaruhi prestasi belajar.

Berdasarkan data di atas, penulis telah melakukan penelitian dengan tujuan untuk mengetahui pengaruh profesionalisme guru terhadap prestasi belajar siswa di salah satu SMK swasta di Lembang dalam mata pelajaran Kearsipan. Hal ini dilakukan karena Mata Pelajaran Kearsipan merupakan salah satu mata pelajaran produktif yang harus dikuasai oleh Siswa Program Keahlian Administrasi Perkantoran. Hal ini dibutuhkan untuk menunjang pekerjaan mereka di masa yang akan datang. Selain itu, mata pelajarn ini akan berdampak terhadap pencapaian tujuan pendidikan.

Berikut dipaparkan beberapa konsep meliputi teori-teori yang berkaitan dengan profesionalisme guru dan prestasi belajar siswa yang mendasari penelitian kuantitatif yang telah dilakukan oleh penulis. Selanjutnya, akan disajikan pemaparan yang berkaitan dengan beberapa hal sebagai berikut: 1) bagaimana penelitian ini dilakukan; 2) metode apa yang digunakan; 3) Instrumen yang digunakan; 4) analisa data yang dilakukan; 5) bahasan dari hasil penelitian; serta 6) kesimpulan dan saran yang dibuat berdasar pada hasil penelitian.

\section{TINJAUAN PUSTAKA \\ Profesionalisme Guru}

Untuk mencapai tujuan pendidikan nasional dibutuhkan guru yang profesional karena profesionalisme guru menduduki posisi sentral dan strategis. Guru yang profesional bukan hanya menguasai materi yang akan diajarkan tetapi menguasai banyak hal terkait tugasnya. Sanaky, (2005) mengungkapkan guru profesional harus menguasai kurikulum, materi pembelajaran, kemampuan mengelola kelas, komit pada tugas, dapat menjaga kode etik profesi, di sekolah ia harus menjadi manusia model yang akan ditiru siswanya, di masyarakat menjadi tauladan.

Bafadal (2009) menegaskan bahwa profesionlisme guru berkaitan dengan kemampuan guru dalam mengelola dirinya sendiri dalam melaksanakan tugas-tugasnya sehari-hari. Riadi (2015) memandang profesionalisme guru berkaitan dengan kewenangan dalam bidang pendidikan dan pengajaran yang berhubungan dengan pekerjaan seseorang yang menjadi mata pencaharian yang meliputi kondisi, arah, nilai, tujuan, dan kualitas suatu keahlian. Lebih lanjut Riadi (2015) menyimpulkan bahwa guru yang dianggap profesional adalah guru yang memiliki kemampuan dan keahlian khusus dalam bidang keguruan sehingga ia mampu melakukan tugas dan fungsinya sebagai guru dengan kemampuan maksimal.

Pengukuran variabel profesionalisme guru dalam penelitian ini meliputi 4 (empat) indikator sebagai berikut: 1) Kompetensi Profesional; 2) Kompetensi Pedagogik; 3) Kompetensi Sosial; 4) Kompetensi Kepribadian (Kunandar, 2009, hlm. 56).

\section{Prestasi Belajar Siswa}


Purwanto (2009, hlm. 67) menyatakan bahwa prestasi belajar meliputi segenap ranah kejiwaan yang berubah sebagai akibat dari pengalaman dan proses belajar siswa yang bersangkutan. Menurut Syah (2010, hlm. 141) bahwa prestasi belajar merupakan hasil interaksi dari sebagian faktor yang mempengarui proses belajar secara keseluruhan yang meliputi segenap ranah psikologis yang berubah sebagai akibat pengalaman dan proses belajar siswa. Sedangkan menurut Tu'u (2004) bahwa Prestasi belajar merupakan penguasaan pengetahuan atau keterampilan mata pelajaran tertentu yang pada umumnya ditunjukkan dengan nilai tes atau skor yang diberikan guru. Pengukuran variabel prestasi belajar siswa dalam penelitian ini adalah nilai akhir semester ganjil pada Mata Pelajaran Kearsipan.

\section{Profesionalisme Guru sebagai Determinan terhadap Prestasi Belajar Siswa}

Tschannen-Moran (2009, hlm. 226) mengemukakan: "These Processes in turn create the condotions that support student learning. As such, teacher professionalism has been found to be positively correlated with student achievement". Proses belajar ini pada gilirannya menciptakan kondisi yang mendukung pembelajaran siswa. Dengan demikian, profesionalisme guru telah ditemukan berkolerasi positif dengan prestasi belajar siswa.

Sependapat dengan Bakar (2018, hlm. 70) menyatakan bahwa "Thus teacher professionalism is one of the important variables that should be considered to improve the student achievement". Dengan demikian, profesionalisme guru adalah salah satu variabel penting yang harus dipertimbangkan untuk meningkatkan prestasi siswa.

Keberhasilan proses pembelajaran dan hasil belajar banyak ditentukan oleh kompetensi guru, selain ditentukan pula oleh sekolah, struktur, dan isi kurikulum, seperti yang diungkapkan oleh Hamalik (2009) bahwa guru yang kompeten akan lebih mampu menciptakan lingkungan belajar yang efektif, menyenangkan, dan akan lebih mampu mengelola kelasnya, sehingga pembelajaran berada pada tingkat yang optimal.

\section{METODE PENELITIAN}

Penelitian ini bertujuan untuk mengetahui gambaran profesionalisme guru dan prestasi belajar siswa. Penelitian ini menggunakan metode eksplanatory survey dengan teknik pengumpulan data menggunakan angket. Sampel dalam penelitian ini, sebanyak 81 responden siswa Kelas X Program Keahlian Administrasi Perkantoran. Sampel ini digunakan untuk mengukur variabel profesionalisme guru sebanyak 30 item yang dijabarkan melalui empat indikator yaitu, kompetensi profesional, kompetensi pedagogik, kompetensi sosial, dan kompetensi kepribadian. Dalam penelitian kuantitatif yang dilakukan penulis, teknik analisa statistik yang digunakan dalam mengolah data adalah teknik analisa deskriptif dan teknik analisa inferensial. Analisa statistik deskriptif digunakan untuk mengetahui gambaran tentang pandangan responden mengenai profesionalisme guru yang dipresentasikan dalam bentuk frekuensi dan persentase. Adapun analisa statistik inferensial digunakan untuk melihat impak dari profesionalisme guru terhadap prestasi belajar serta untuk menguji hipotesis yang diuji menggunakan regresi sederhana, dan uji hipotesis.

\section{HASIL PENELITIAN DAN PEMBAHASAN}

Untuk mengetahui gambaran empiris tentang bagaimana sikap, pendapat dan persepsi siswa terhadap profesionalisme guru dan prestasi belajar siswa kelas X pada mata pelajaran kearsipan Administrasi Perkantoran di salah satu SMK swasta di 
Lembang, terlebih dahulu dibuatkan suatu ukuran standar sebagai pembanding yaitu dengan menetapkan skor kriterium dengan menggunakan langkah-langkah menurut Muhidin dan Somantri (2006) adalah sebagai berikut:

a) menentukan jumlah Skor Kriterium (SK)

b) tentukan lebar interval

c) menetapkan batas rendah dan batas atas.

Berdasarkan hasil perhitungan dari langkah-langkah di atas, maka dapat disimpulkan dalam rekapitulasi skor kriterium antara lain seperti di bawah ini:

Tabel 2

Skala Penafsiran Skor Rata-rata Variabel X

\begin{tabular}{|c|c|c|}
\hline No. & Rentang & Penafsiran \\
\hline 1 & & $\mathbf{X}$ \\
\hline 2 & $1,00-1,79$ & Sangat Kurang \\
\hline 3 & $2,80-2,59-3,39$ & Kurang \\
\hline 4 & $3,40-4,19$ & Cukup Baik \\
\hline 5 & $4,20-5,00$ & Baik \\
\hline
\end{tabular}

Sumber: (Sugiyono, 2009:169)

Tabel 3

Skala Penafsiran Skor Rata-rata Variabel Y

\begin{tabular}{|c|c|c|}
\hline \multirow{2}{*}{ No. } & Rentang & Penafsiran \\
\cline { 3 - 3 } & & Y \\
\hline 1. & $60,25-68,25$ & Sangat Rendah \\
\hline 2. & $68,25-76,25$ & Rendah \\
\hline 3. & $76,25-84,25$ & Sedang \\
\hline 4. & $84,25-92,25$ & Tinggi \\
\hline 5. & $92,25-100$ & Sangat Tinggi \\
\hline
\end{tabular}

Sumber: Diadaptasi dari nilai akhir siswa

\section{Profesionalisme Guru}

Dari hasil pengolahan data, dapat disimpulkan bahwa hasil skor rata-rata variabel profesionalisme guru sebesar 2,76. Jika diklasifikasikan dengan skala penafsiran pada tabel tentang Kriteria Penafsiran Deskripsi maka, angka tersebut berada pada rentang 2,60 - 3,39 atau berada pada kategori cukup baik, seperti terlihat pada Tabel 4 berikut ini:

Tabel 4

Rekapitulasi Tanggapan Responden terhadap Variabel X Profesionalisme Guru

\begin{tabular}{|l|c|c|c|}
\hline \multicolumn{1}{|c|}{ Indikator } & Item & Rata-rata & Penafsiran \\
\hline Kompetensi profesional & $1-7$ & 2,65 & Cukup Baik \\
\hline Kompetensi pedagogik & $8-18$ & 2,61 & Cukup Baik \\
\hline Kompetensi sosial & $19-27$ & 2,64 & Cukup Baik \\
\hline Kompetensi kepribadian & $28-30$ & 3,14 & Cukup Baik \\
\hline \multicolumn{2}{|c|}{ Rata-rata Variabel X } & $\mathbf{2 , 7 6}$ & Cukup Baik \\
\hline
\end{tabular}


Sumber: Skor Hasil Pengolahan Jawaban Responden

Sedangkan, berdasarkan hasil perhitungan yang diperoleh mengenai indikator profesionalisme guru dapat digambarkan pada diagram di bawah ini, sebagai berikut:

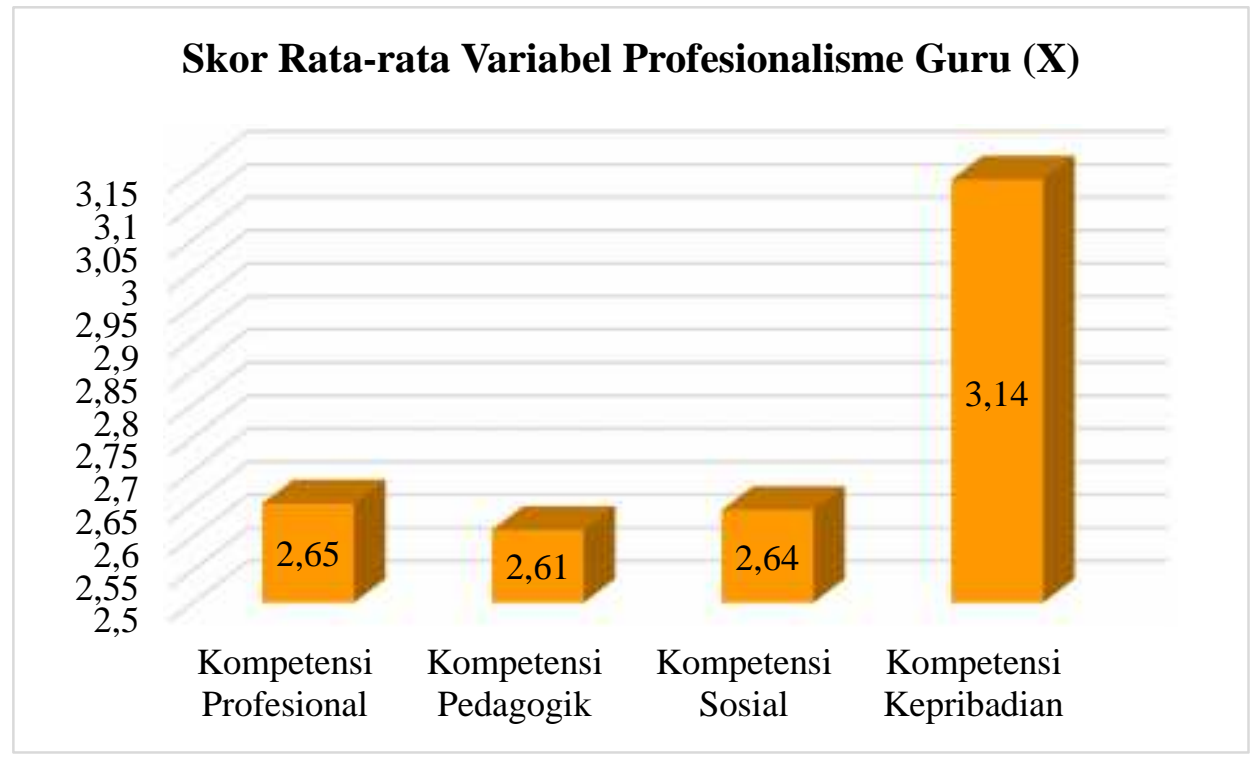

\section{Gambar 1 \\ Rekapitulasi Perhitungan Data Variabel Profesionalisme Guru}

Gambar 2 menunjukkan bahwa nilai skor rata-rata jawaban tertinggi pada Variabel Profesionalisme Guru adalah indikator kompetensi kepribadian sebesar 3,14 dan skor terendah adalah indikator kompetensi pedagogik sebesar 2,61.

\section{Prestasi Belajar Siswa}

Hasil pengolahan data laporan prestasi belajar siswa pada Mata Pelajaran Kearsipan Semester Ganjil Tahun Ajaran 2017/2018 Kelas X Administrasi Perkantoran sudah optimal. Hal ini terlihat dari banyaknya siswa yang mencapai Kriteria Ketuntasan Minimal (KKM). Siswa yang mencapai nilai KKM sebanyak 69 orang dari 81 orang siswa atau seluruh total responden.

Rata-rata nilai akhir siswa pada Mata Pelajaran Kearsipan mencapai nilai 82,11 dengan nilai maksimum sebesar 93,00 dan nilai minimum sebesar 68,00. Jika dihubungkan dengan penafsiran skor deskriptif nilai akhir pada tabel sebelumnya maka rata-rata nilai akhir siswa berada pada rentang 76,25-84,25 yang termasuk pada kategori sedang.

Maka dari itu, dapat disimpulkan bahwa secara rata-rata hasil Nilai Akhir Kelas X Semester Ganjil Mata Pelajaran Kearsipan di salah satu SMK swasta di Lembang tergolong sedang.

\section{Profesionalisme Guru sebagai Determinan Prestasi Belajar Siswa}

Dari hasil analisa regresi sederhana yang bertujuan untuk melihat pengaruh dari variabel profesionalisme guru terhadap prestasi belajar. Diperolehlah persamaan regresi 
$\hat{\mathrm{Y}}=6595,434+0,679(\mathrm{X})$. Tanda (+) di depan angka 0,679 menunjukkan hubungan antara variabel bebas (profesionalisme guru) dan variabel terikat (prestasi belajar siswa) berjalan satu arah. Apabila semakin tinggi profesionalisme guru maka semakin tinggi pula prestasi belajar siswa begitupun sebaliknya.

Perhitungan pengujian hipotesis maka diperoleh $t_{\text {hitung }}>t_{\text {tabel }}$ dengan nilai $39,831>3,962$. Karena nilai $t_{\text {hitung }}$ lebih besar dari pada $t_{\text {tabel }}$ sehingga dapat disimpulkan bahwa "Terdapat Pengaruh Profesionalisme Guru terhadap Prestasi Belajar Siswa Kelas X AP pada Mata Pelajaran Kearsipan di salah satu SMK swasta di Lembang".

Nilai koefisien determinasi variabel profesionalisme guru dan variabel prestasi belajar siswa sebesar 33,52\%. Artinya, secara parsial profesionalisme guru memiliki pengaruh terhadap prestasi belajar sebesar 33,52\%. Sisanya sebesar 66,48\% dipengaruhi oleh faktor lain yang memengaruhi prestasi belajar siswa.

\section{KESIMPULAN}

Profesionalisme guru dalam penelitian ini berada pada ketegori cukup baik. Profesionalisme guru tersebut diukur menggunakan 4 (empat) indikator yaitu: Kompetensi Profesional, Kompetensi Pedagogik, Kompetensi Sosial, dan Kompetensi Kepribadian.

Indikator Kompetensi Kepribadian memiliki tingkat persentase tertinggi, sedangkan indikator Kompetensi Pedagogik memiliki tingkat persentase terendah. Sementara prestasi belajar siswa dalam penelitian ini berada pada kategori sedang yang ditandai dengan sudah banyaknya siswa yang mencapai Kriteria Ketuntasan Minimal (KKM).

Profesionalisme guru mempunyai pengaruh yang positif dan signifikan terhadap prestasi belajar siswa kelas X Administrasi di salah satu SMK swasta di Lembang. Hal ini mengindikasikan bahwa profesionalisme guru akan mempengaruhi prestasi belajar siswa. Saran yang dapat diberikan dalam kajian ini adalah terkait indikator profesionalisme guru yang perlu mendapatkan perhatian lebih yaitu, kompetensi pedagogik. Implikasi yang dapat diambil dari penelitian ini adalah untuk menigkatkan prestasi belajar siswa diharapkan adanya peningkatan dan pengembangan profesionalisme guru dalam upaya meningkatkan prestasi belajar siswa.

\section{DAFTAR PUSTAKA}

Bafadal, I. (2009). Peningkatan Profesionalisme Guru. Jakarta: PT. Bumi Aksara.

Bakar, R. (2018). The Influence of Professional Teachers on Padang Vocational School Student's Achievment. Social Sciences, 67-72.

Hamalik, O. (2009). Proses Belajar Mengajar. Bandung: Sinar Grafika Offset.

Kunandar. (2009). Guru professional implementasi kurikulum tingkat satuan. Jakarta: Rajawali Press.

Latipah, E. (2010). Strategi Self Regulated Learning dan Prestasi Belajar: Kajian Meta Analisis. Jurnal Psikologi, 110-129.

Purwanto, N. (2009). Prinsip-prinsip dan Teknik Evaluasi Pengajaran. Bandung: PT. Remaja Rosdakarya. 
Riadi, M. (2015). Profesionalisme dan Kompetensi Guru. tersedia di https://www.kajianpustaka.com/2015/11/profesionalisme-dan-kompetensiguru.html

Sanaky, H. A. (2005). Sertifikasi dan Profesionalisme Guru di Era Reformasi Pendidikan. 29-45.

Muhidin, S.A. Somantri,. A. (2006). Aplikasi Statistik dalam Penelitian. Bandung: Pustaka Setia.

Sudjana, N. (2013). Penilaian Hasil Proses Belajar Mengajar. Bandung: Remaja Rosdakarya.

Sugiyono. (2009). Metode Penelitian Pendidikan. Bandung: Alfabeta.

Syah, M. (2010). Psikologi Pendidikan dengan Pendekatan Baru. Bandung: PT. Remaja Rosdakarya.

Tschannen-Moran, M. (2009). Fostering Teacher Professionalism in Schools The Role of Leadership Orientation and Truts. Educational Administration Quarterly, 217-247.

Tu'u, T. (2004). Peran Disiplin pada Perilaku dan Prestasi Siswa. Jakarta: PT Grasindo. 